Tatsuya Ichinohe DDS PhD, Hidetaka Aida DDS PhD, Yuzuru Kaneko DDS PhD

\section{Interaction of nitrous oxide and propofol to reduce hypertensive response to stimulation}

Purpose: To evaluate the interaction between nitrous oxide and propofol for the suppression of hypertension following electrical stimulation of the mental nerve in the rabbit.

Methods: Male Japan White rabbits were tracheostomized, cannulated and mechanically ventilated under isoflurane anesthesia. Square wave pulses $(5 \mathrm{~V}, 0.5 \mathrm{msec}, 50 \mathrm{~Hz}$ for $5 \mathrm{sec}$ ) were delivered to the left mental nerve. Animals received nitrous oxide 20, 40, 60 and 80\% (Group I); propofol 200, 400, 600 and $800 \mu \mathrm{g} \cdot \mathrm{kg}^{-1} \cdot \mathrm{min}^{-1}$ (Group 2); or combinations of nitrous oxide and propofol at $10+100,20+200,30+300$ and $40 \%+400$ $\mu \mathrm{g} \cdot \mathrm{kg}^{-1} \cdot \mathrm{min}^{-1}$ (Group 3). Systolic blood pressure was recorded from immediately before to maximal increase following nerve stimulation. Probit analysis was used to obtain $\mathrm{ED}_{50}$ values for $50 \%$ suppression of blood pressure elevation. Isobolographic analysis was used to evaluate the interaction between nitrous oxide and propofol.

Results: $E_{50}$ values are $52.9 \%$ for nitrous oxide (Group I), $464.1 \mu \mathrm{g} \cdot \mathrm{kg}^{-1} \cdot \mathrm{min}^{-1}$ for propofol (Group 2), 21.7 $\%+217.1 \mu \mathrm{g} \cdot \mathrm{kg}^{-1} \cdot \mathrm{min}^{-1}$ for nitrous oxide and propofol combination (Group 3) and $24.7 \%+247.1$ $\mu \mathrm{g} \cdot \mathrm{kg}^{-1} \cdot \mathrm{min}^{-1}$ for the theoretically additive combination of nitrous oxide and propofol, respectively.

Conclusion: The interaction between nitrous oxide and propofol for the suppression of blood pressure elevation following electrical stimulation of the mental nerve is additive.

Objectif : Évaluer l'interaction entre le protoxyde d'azote et le propofol, utilisés comme antihypertenseurs, à la suite d'une stimulation électrique du nerf mentonnier chez le lapin.

Méthode: Des lapins albinos mâles du Japon ont subi une trachéotomie, la mise en place d'une canule trachéale et une ventilation mécanique sous anesthésie à l'isoflurane. Un courant d'ondes carrées $(5 \mathrm{~V}, 0,5 \mathrm{msec}, 50 \mathrm{~Hz}$ pendant $5 \mathrm{sec}$ ) a été administré au nerf mentonnier gauche. Les animaux ont reçu 20, 40, 60 et $80 \%$ de protoxyde d'azote (Groupe I); 200, 400, 600 et $800 \mu \mathrm{g} \mathrm{kg}^{-1} \cdot \mathrm{min}^{-1}$ de propofol (Groupe 2) ou une combinaison de protoxyde d'azote et de propofol : $10+100,20+200,30+300$ et $40 \%+400 \mu \mathrm{g}^{\mathrm{kg}} \mathrm{kg}^{-1} \cdot \mathrm{min}^{-1}$ (Groupe 3). La tension artérielle systolique a été enregistrée à partir du moment qui précède immédiatement l'augmentation jusqu'à l'élévation maximale provoquée par la stimulation du nerf. Une analyse par la méthode des probits a été utilisée pour obtenir la valeur de $\mathrm{ED}_{50}$ qui correspond à la suppression de $50 \%$ de l'élévation de la pression sanguine. L'analyse isobolographique a permis d'évaluer l'interaction entre le protoxyde d'azote et le propofol.

Résultats : La valeur de $\mathrm{ED}_{50}$ était de 52,9\% pour le protoxyde d'azote (Groupe I); 464, I $\mu \mathrm{g} \cdot \mathrm{kg}^{-1} \cdot \mathrm{min}^{-1}$ pour le propofol (Groupe 2); $21,7 \%+217,1 \mu \mathrm{g} \cdot \mathrm{kg}^{-1} \cdot \mathrm{min}^{-1}$ pour la combinaison de protoxyde d'azote et de propofol (Groupe 3) et de $24,7 \%+247,1 \mu \mathrm{g} \cdot \mathrm{kg}^{-1} \cdot \mathrm{min}^{-1}$ pour la combinaison additive théorique de protoxyde d'azote et de propofol, respectivement.

Conclusion : L'interaction entre le protoxyde d'azote et le propofol, utilisés comme antihypertenseurs à la suite d'une stimulation électrique du nerf mentonnier, est additive.

From the Department of Dental Anesthesiology, Tokyo Dental College, 1-2-2, Masago, Mihama-ku, Chiba, 261-0011 Japan. Address correspondence to: Dr. Tatsuya Ichinohe. Phone: 81-43-270-3969; Fax: 81-43-270-3971; E-mail: ichinohe@tdc.ac.jp Accepted for publication April 17, 2000. 
$\mathrm{T}$

OTAL intravenous anesthesia is widely used in clinical anesthesia. Propofol-based total intravenous anesthesia produces stable hemodynamic conditions during surgery accompanied with early emergence and low incidence of postoperative nausea and vomiting. In some cases, however, hemodynamic fluctuations including blood pressure elevation are large enough to interrupt the surgery. Nitrous oxide may be added in such cases.

Fifty percent nitrous oxide inhibits the blood pressure elevation following electrical stimulation of the mental nerve in the rabbit. ${ }^{1}$ The interaction between nitrous oxide and propofol evaluated by movement after skin incision in anesthetized patients was reported to be additive, although the effect is not as great as the sum of the two would suggest. ${ }^{2}$ However, no study has evaluated the interaction of these agents on the basis of blocking cardiovascular responses to noxious stimulation. Minimal hemodynamic fluctuation and no movement response are desirable during general anesthesia.

The purpose of the present study was to evaluate the interaction between nitrous oxide and propofol on the basis of suppressing blood pressure elevation following electrical stimulation of the mental nerve in the rabbit.

Materials and methods

After approval by the Animal Care and Use Committee, Tokyo Dental College, we utilized male Japan White rabbits $(2.1-2.8 \mathrm{~kg})$. Animals were allowed food and water ad libitum until the morning of the experiment. Anesthesia was induced by inhalation of isoflurane (2.0 $\mathrm{v} / \mathrm{v} \%)$ in oxygen delivered via a mask. Before skin incision for each of the experimental procedures, except for the mental nerve isolation, appropriate doses of lidocaine were infiltrated into the surgical field. A \#20 French, non-cuffed pediatric endotracheal tube was inserted into the trachea through a tracheostomy. The left auricular marginal vein and right femoral artery were cannulated with 22 and 20 gauge Teflon indwelling catheters (Angiocath, Becton Dickinson, Sandy, Utah). After lactated Ringer's solution was started at $10 \mathrm{ml} \cdot \mathrm{kg}^{-1} \cdot \mathrm{hr}^{-1} \mathrm{iv}$, the animals were paralyzed with $1 \mathrm{mg} \cdot \mathrm{kg}^{-1}$ alcuronium iv (Dialferin, Roche, Tokyo, Japan) and their lungs were mechanically ventilated with an animal ventilator (Model 613, Harvard, South Natick, Massachusetts). The femoral artery blood pressure was continuously monitored with a pressure transducer (P23ID; Gould, Oxnard, California). The blood pressure changes were continuously recorded (Polygraph series 360; NEC Sanei, Tokyo, Japan).

Through a $10 \mathrm{~mm}$ incision in the left mental region, the left mental nerve was isolated. The nerve was placed over a pair of stainless needle hook electrodes with the cathode at the proximal site and covered with a layer of liquid paraffin. Square wave pulses were delivered using a stimulation unit (SEN-7203, Nihon Kohden, Tokyo, Japan) and an isolation unit (SS-104J, Nihon Kohden, Tokyo, Japan). The stimulating condition was $5 \mathrm{~V}$ in intensity and $0.5 \mathrm{msec}$ duration, at a frequency of $50 \mathrm{~Hz}$ for $5 \mathrm{sec}$.

After the completion of experimental preparations, the end-tidal concentration of isoflurane was reduced to $0.7 \%$, (approximately $0.35 \mathrm{MAC})^{3}$ and kept at that concentration throughout the experiment. More than $60 \mathrm{~min}$ was allowed to elapse to stabilize blood pressure in each animal. In group $1(n=9)$, following control assessment, measurements were repeated with nitrous oxide (end-tidal concentration) inhalation at 20,40, 60 and $80 \%$ in this order. In group $2(\mathrm{n}=9)$, following control assessment, measurements were repeated at 200 , 400,600 and $800 \mu \mathrm{g} \cdot \mathrm{kg}^{-1} \cdot \mathrm{min}^{-1}$ propofol (Diprivan, Astra-Zeneka, Tokyo, Japan) infusion rates in this order. In group $3(\mathrm{n}=9)$, following the control, measurements were repeated at nitrous oxide $10 \%+100$ $\mu \mathrm{g} \cdot \mathrm{kg}^{-1} \cdot \mathrm{min}^{-1}$ propofol, nitrous oxide $20 \%+200$ $\mu \mathrm{g} \cdot \mathrm{kg}^{-1} \cdot \mathrm{min}^{-1}$ propofol, nitrous oxide $30 \%+300$ $\mu \mathrm{g} \cdot \mathrm{kg}^{-1} \cdot \mathrm{min}^{-1}$ propofol and nitrous oxide $40 \%+400$ $\mu \mathrm{g} \cdot \mathrm{kg}^{-1} \cdot \mathrm{min}^{-1}$ propofol in this order. Each administration was continued for $20 \mathrm{~min}$. Electrical stimulation was made 15 and 20 min after the start of each administration. Systolic blood pressure (SBP) immediately before (Pre) and at maximal increase (Max) following the nerve stimulation was recorded. The SBP elevations from Pre to Max (delta SBP) at 15 and 20 min after the start of each administration were calculated and averaged. To ascertain if changes in the baseline blood pressure had any effect on delta SBP, a group of six rabbits was studied. The SBP was reduced to about $80 \mathrm{mmHg}$ with sodium nitroprusside (SNP, Wako, Osaka, Japan) or elevated to about $150 \mathrm{mmHg}$ with phenylephrine (Neosynesin, Kowa, Tokyo, Japan) during the inhalation of 0.35 MAC isoflurane. Electrical stimulation was given at five minute intervals during SNP and phenylephrine infusion.

The $\mathrm{P}_{\mathrm{ET}} \mathrm{CO}_{2}$ was kept constant $(35-40 \mathrm{mmHg}$ ) throughout the experiment. End-tidal nitrous oxide and isoflurane concentrations and $\mathrm{P}_{\mathrm{ET}} \mathrm{CO}_{2}$ were continuously monitored with an anesthetic gas monitor (Capnomac; Datex, Helsinki, Finland). Body temperature was continuously monitored by a rectal probe and maintained between $39.0-39.5^{\circ} \mathrm{C}$ with the aid of a heating lamp.

The Pre and delta SBP are shown as the mean \pm SD. One-way analysis of variance for repeated measurements followed by Dunnett test was used for intragroup com- 
TABLE I Systolic blood pressure (SBP, $\mathrm{mmHg}$ ) immediately before (Pre SBP) and maximal SBP elevation (delta SBP) following electrical stimulation of the mental nerve.

\begin{tabular}{|c|c|c|c|}
\hline & & Pre $S B P$ & delta $S B P$ \\
\hline \multirow[t]{5}{*}{ Group 1} & Control & $124.2 \pm 17.5$ & $37.3 \pm 11.9$ \\
\hline & $20 \% \mathrm{~N}$ & $130.6 \pm 20.6^{*}$ & $33.9 \pm 13.8$ \\
\hline & $40 \% \mathrm{~N}$ & $137.1 \pm 20.9^{*}$ & $24.4 \pm 18.0$ \\
\hline & $60 \% \mathrm{~N}$ & $143.1 \pm 18.8^{*}$ & $17.2 \pm 12.7$ \\
\hline & $80 \% \mathrm{~N}$ & $146.7 \pm 16.5^{*}$ & $11.7 \pm 14.1$ \\
\hline \multirow[t]{5}{*}{ Group 2} & Control & $133.1 \pm 12.3$ & $31.7 \pm 10.3$ \\
\hline & $200 \mu \mathrm{g} \cdot \mathrm{kg}^{-1} \cdot \mathrm{min}^{-1} \mathrm{P}$ & $127.2 \pm 13.1$ & $27.6 \pm 8.5$ \\
\hline & $400 \mu \mathrm{g} \cdot \mathrm{kg}^{-1} \cdot \mathrm{min}^{-1} \mathrm{P}$ & $123.8 \pm 16.1^{*}$ & $16.4 \pm 10.6$ \\
\hline & $600 \mu \mathrm{g} \cdot \mathrm{kg}^{-1} \cdot \mathrm{min}^{-1} \mathrm{P}$ & $115.9 \pm 14.1^{*}$ & $10.3 \pm 8.2$ \\
\hline & $800 \mu \mathrm{g} \cdot \mathrm{kg}^{-1} \cdot \mathrm{min}^{-1} \mathrm{P}$ & $109.6 \pm 11.9^{*}$ & $9.6 \pm 8.3$ \\
\hline \multirow[t]{5}{*}{ Group 3} & Control & $121.6 \pm 13.5$ & $32.8 \pm 11.3$ \\
\hline & $10 \% \mathrm{~N}+100 \mu \mathrm{g} \cdot \mathrm{kg}^{-1} \cdot \mathrm{min}^{-1} \mathrm{P}$ & $123.9 \pm 13.7$ & $25.6 \pm 11.8$ \\
\hline & $20 \% \mathrm{~N}+200 \mu \mathrm{g} \cdot \mathrm{kg}^{-1} \cdot \mathrm{min}^{-1} \mathrm{P}$ & $124.3 \pm 12.0$ & $16.9 \pm 14.0$ \\
\hline & $30 \% \mathrm{~N}+300 \mu \mathrm{g} \cdot \mathrm{kg}^{-1} \cdot \mathrm{min}^{-1} \mathrm{P}$ & $123.7 \pm 9.8$ & $15.2 \pm 12.5$ \\
\hline & $40 \% \mathrm{~N}+400 \mu \mathrm{g} \cdot \mathrm{kg}^{-1} \cdot \mathrm{min}^{-1} \mathrm{P}$ & $124.2 \pm 10.3$ & $9.4 \pm 11.0$ \\
\hline \multirow[t]{2}{*}{ SNP } & Control & $115.5 \pm 10.2$ & $29.8 \pm 11.8$ \\
\hline & Infusion & $75.5 \pm 5.6^{*}$ & $25.0 \pm 10.3$ \\
\hline \multirow[t]{2}{*}{ Phenylephrine } & Control & $120.5 \pm 10.5$ & $30.2 \pm 10.6$ \\
\hline & Infusion & $153.9 \pm 14.7^{*}$ & $28.6 \pm 11.1$ \\
\hline
\end{tabular}

Data are expressed as mean $\pm \mathrm{SD} . \mathrm{N}=$ nitrous oxide; $\mathrm{P}=$ propofol; $\mathrm{SNP}=$ sodium nitroprusside. Asterisk in the "Pre" column indicates significant difference $(P<0.05)$ from control in each group.

parison of SBP values at Pre in each group. One-way analysis of variance followed by Student-Newman-Keuls test was used for intergroup comparison of the SBP values at Pre and the delta SBP values at the control period. A $P$ value $<0.05$ was considered statistically significant. Probit analysis ${ }^{4}$ was used to obtain $\mathrm{ED}_{50}$ values to suppress blood pressure elevation for nitrous oxide, propofol and nitrous oxide - propofol combination. Delta SBP at each measurement period was expressed as the percentage from the respective control value in each group. Four values of the percentage changes were plotted against logarithmic values of the respective administered concentration / rate and served for probit analysis. The $\mathrm{ED}_{50}$ values were calculated as the administered concentration / rate producing a delta SBP of $50 \%$ of that during the control stimulation. Data are expressed as the $\mathrm{ED}_{50}$ value with $95 \%$ confidence interval in the parenthesis. Isobolographic analysis ${ }^{4-6}$ was used to evaluate the interaction between nitrous oxide and propofol. An isobologram was constructed by plotting $\mathrm{ED}_{50}$ values on the $\mathrm{x}$ and $\mathrm{y}$ axes ( $\mathrm{x}$ for nitrous oxide and $y$ for propofol). A straight line joining the two $\mathrm{ED}_{50}$ values is the theoretical additive line. Deviation of the $\mathrm{ED}_{50}$ for the nitrous oxide-propofol combination to the left from the theoretical additive line indicates a supraadditive (synergistic) effect and; to the right, an infraadditive (antagonistic) effect. The deviation was considered statistically significant when the $95 \%$ confi-

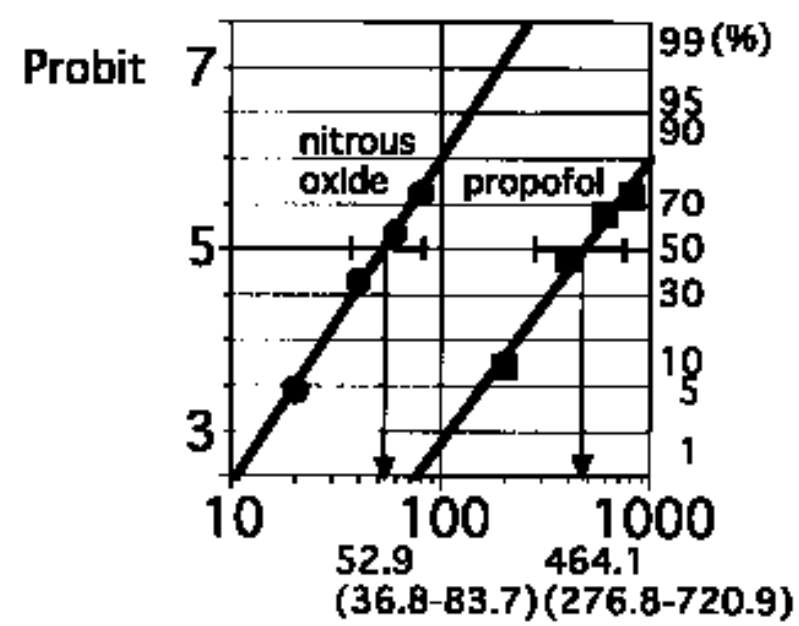

FIGURE 1 Probit analyses to obtain the $\mathrm{ED}_{50}$ values of nitrous oxide and propofol for $50 \%$ suppression of blood pressure elevation following the electrical stimulation of the mental nerve. $\mathrm{ED}_{50}$ values $(95 \%$ confidence interval) are $52.9(36.8-83.7) \%$ for nitrous oxide and $464.1\left(276.8\right.$ - 720.9) $\mu \mathrm{g} \cdot \mathrm{kg}^{-1} \cdot \mathrm{min}^{-1}$ for propofol, respectively.

dence intervals of the $\mathrm{ED}_{50}$ for nitrous oxide-propofol combination in both $\mathrm{x}$ and $\mathrm{y}$ directions did not overlap those of the $\mathrm{ED}_{50}$ point for the theoretically additive combination of nitrous oxide and propofol. 
Results

The SBP at Pre in the control period were $124.2 \pm 17.5$ $\mathrm{mmHg}$ in group $1,133.1 \pm 12.3 \mathrm{mmHg}$ in group 2 and $121.6 \pm 13.5 \mathrm{mmHg}$ in group 3 , respectively. The SBP in group 2 was higher than in the other two groups $(P<0.05)$, although the differences were about 10 $\mathrm{mmHg}$. The SBP increased during nitrous oxide inhalation in group $1(P<0.05)$, while SBP decreased during propofol infusion in group $2(P<0.05)$. The SBP did not change during concomitant administration of nitrous oxide and propofol in group 3. Delta SBP values in the control period were $37.3 \pm 11.9 \mathrm{mmHg}$ in group $1,31.7 \pm 10.3 \mathrm{mmHg}$ in group 2 and $32.8 \pm$ $11.3 \mathrm{mmHg}$ in group 3 , respectively ( $P$. NS). Delta SBP values during SNP or phenylephrine infusion were not different from their control values (Table I).

Figure 1 demonstrates probit analyses to obtain the $\mathrm{ED}_{50}$ values of nitrous oxide and propofol for $50 \%$ suppression of blood pressure elevation following electrical stimulation of the mental nerve. Table II summarizes the results. The $\mathrm{ED}_{50}$ values (95\% confidence interval) are 52.9 (36.8 - 83.7)\% for nitrous oxide, 464.1 (276.8 - 720.9) $\mu \mathrm{g} \cdot \mathrm{kg}^{-1} \cdot \mathrm{min}^{-1}$ for propofol and 21.7 (9.8 $39.7) \%+217.1(97.6-397.3) \mu \mathrm{g} \cdot \mathrm{kg}^{-1} \cdot \mathrm{min}^{-1}$ for nitrous oxide and propofol combination, respectively. The $\mathrm{ED}_{50}$ values $(95 \%$ confidence interval) for the theoretically additive combination of nitrous oxide and propofol are 24.7 (13.0 - 51.3)\% and 247.1 (129.6 - 512.8) $\mu \mathrm{g} \cdot \mathrm{kg}^{-1} \cdot \mathrm{min}^{-1}$, respectively. Isobolographic analysis shows that the interaction between nitrous oxide and propofol is additive (Figure 2).

Discussion

The present study demonstrates that the interaction between nitrous oxide and propofol in suppressing blood pressure elevation following electrical stimulation of the mental nerve is additive. Hemodynamic changes following electrical stimulation of the mental nerve were not inhibited during SNP-induced reduction or phenylephrine-induced elevation in SBP. These results suggest that inhibition of blood pressure eleva-

TABLE II $\mathrm{ED}_{50}$ values and their $95 \%$ confidence intervals for $50 \%$ suppression of blood pressure elevation following the electrical stimulation of the mental nerve.

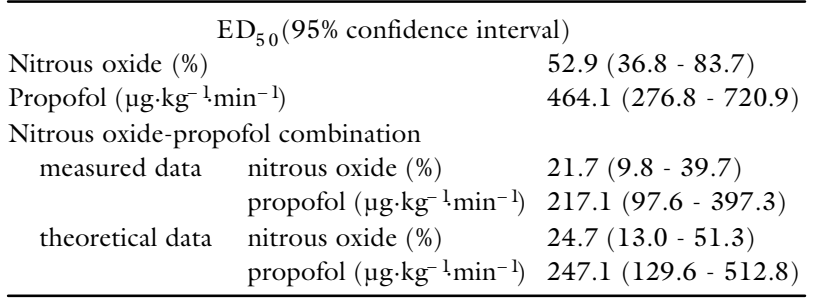

tion following electrical stimulation of the mental nerve during the administration of nitrous oxide, propofol or nitrous oxide - propofol combination was caused not by the changes in SBP but by their pharmacological effects. In this study, only SBP changes following electrical stimulation of the mental nerve were observed. In discussing the cardiovascular effects of anesthetic agents, changes in heart rate as well as in blood pressure should be considered. In the present study, however, heart rate decreased in some cases after electrical stimulation of the mental nerve probably due to baroreceptor reflex mechanisms. Accordingly, delta SBP was used to evaluate the interaction between nitrous oxide and propofol.

Sixty seven percent nitrous oxide in oxygen (approximately $0.6 \mathrm{MAC}$ ) reduced the predicted effective blood concentration of propofol by $25 \%$ in preventing the movement response to surgical incision in anesthetized patients. ${ }^{2}$ The authors speculated that the interaction between nitrous oxide and propofol was additive, though the effect was not as great as the sum of the two would suggest. However, this conclusion did not come from an isobolographic analysis.

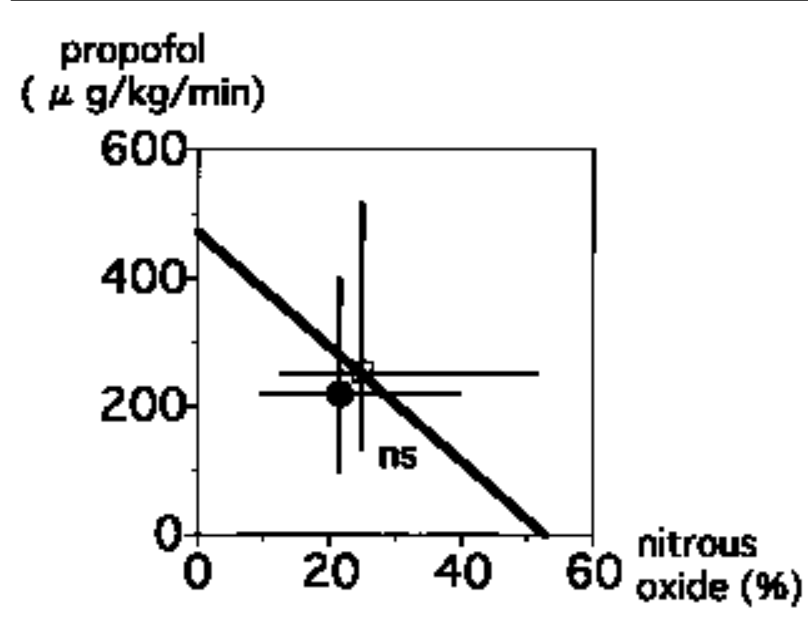

FIGURE 2 Isobolographic analysis of the interaction between nitrous oxide and propofol for $50 \%$ suppression of blood pressure elevation following the electrical stimulation of the mental nerve. The theoretically additive line connects the $\mathrm{ED}_{50}$ values of nitrous oxide (52.9\%) and propofol $\left(464.1 \mu \mathrm{g} \cdot \mathrm{kg}^{-1} \cdot \mathrm{min}^{-1}\right)$. An open square on the theoretically additive line shows the $\mathrm{ED}_{50}$ point of the theoretically additive combination of nitrous oxide and propofol. A closed circle shows the $\mathrm{ED}_{50}$ point of the measured combination of nitrous oxide and propofol. Vertical and horizontal bars show $95 \%$ confidence intervals of each $\mathrm{ED}_{50}$ value. The deviation of the $\mathrm{ED}_{50}$ point of the measured combination of nitrous oxide and propofol from the theoretically additive line was statistically insignificant. 
Blood pressure elevation following electrical stimulation of a somatic nerve is mediated by the somatosympathetic reflex. ${ }^{7,8}$ The pathway of the somatosympathetic reflex in the trigeminal region includes the afferent trigeminal nerve fibres, the caudal part of the spinal trigeminal nucleus, the parabrachial nucleus, the rostral ventrolateral medulla and the efferent sympathetic nerve fibres. ${ }^{9}, 10$

Nitrous oxide $75 \%$ suppressed the spontaneous firing frequency of the caudal part of the spinal trigeminal nucleus. ${ }^{11}$ In addition, anesthetic concentrations of nitrous oxide may activate the descending inhibitory system through supraspinal opiate and spinal receptors. ${ }^{12}$ The noradrenergic pathway is involved in the descending inhibitory system in the caudal part of the spinal trigeminal nucleus. ${ }^{13}$ In contrast, there is no direct evidence of the inhibitory effects of propofol on the cellular activities of the caudal part of the spinal trigeminal nucleus. However, propofol activates $\mathrm{GABA}_{\mathrm{A}}$ receptor-chloride ionophore complex in the rat, ${ }^{14}$ and GABAergic neurons may be associated with presynaptic and postsynaptic inhibition within the nociceptive pathways in the caudal part of the spinal trigeminal nucleus. ${ }^{5}$ Thus, inhibition of the cellular activities in the caudal part of the spinal trigeminal nucleus by nitrous oxide or propofol may be accompanied by suppression of the blood pressure responses mediated by the somatosympathetic reflex. ${ }^{16}$

Propofol principally inhibits the vasomotor mechanism in the rostral ventrolateral medulla to effect its hypotensive actions. ${ }^{17}$ Although the effects of nitrous oxide on the rostral ventrolateral medulla are not clarified, nitrous oxide increases the sympathetic activity through actions at the suprapontine level. ${ }^{18}$

Drugs acting via the same mechanisms interact additively, whereas synergy can result from interactions of drugs with different mechanisms of action, in their hypnotic interaction. ${ }^{19}$ The additive interaction of nitrous oxide and propofol in the present study therefore suggests that these agents may act at the same site. Thus, although the mediators for the inhibition of the cellular activity may be different, both nitrous oxide and propofol inhibit cellular activity in the caudal part of the spinal trigeminal nucleus and suppress blood pressure elevation following electrical stimulation of the mental nerve. However, this hypothesis conflicts with the fact that nitrous oxide has analgesic effects while propofol does not. The difference in the chemical mediators between opioids and norepinephrine for nitrous oxide and GABA for propofol may explain this discrepancy. Further studies in this field are needed.

In the clinical settings, although there is no report of the hypnotic interaction, the interactions to suppress movement and blood pressure responses following noxious stimulations are additive between nitrous oxide and propofol. Moreover, there is no interaction between these agents for baroreceptor reflex responses. ${ }^{2}$ Thus, although propofol and fentanyl show synergistic interaction with respect to the suppression of somatic or hemodynamic responses to noxious stimulation, ${ }^{21}$ the addition of nitrous oxide to total intravenous anesthesia using propofol and fentanyl is expected to show only additive effects to suppress blood pressure elevation, while nitrous oxide compensates for the blood pressure reduction caused by propofol.

Since 0.35 MAC isoflurane was given as basal anesthesia to the animals participating in this study for ethical reasons, cardiovascular effects of isoflurane might be involved in the interaction between nitrous oxide and propofol. Further studies under different basal anesthesia using urethane/chloralose or pentobarbital may be needed to clarify this issue.

In conclusion, nitrous oxide and propofol interact additively in the suppression of blood pressure elevation following electrical stimulation of the mental nerve.

\section{References}

1 Ichinohe T, Agata H, Aida H, Kaneko $\Upsilon$. The effects of nitrous oxide and isoflurane on the somatosympathetic reflex during electrical stimulation of the mental nerve in rabbits. Anesth Analg 1997; 84: S498.

2 Davidson JAH, Macleod AD, Howie JC, White M, Kenny GNC. Effective concentration 50 for propofol with and without $67 \%$ nitrous oxide. Acta Anaesthesiol Scand 1993; 37: 458-64.

3 Drummond JC. MAC for halothane, enflurane, and isoflurane in the New Zealand White rabbit: and a test for the validity of MAC determinations. Anesthesiology 1985; 62: 336-8.

4 Gessner PK. Isobolographic analysis of interactions: an update on applications and utility. Toxicology 1995; 105: 161-79.

5 Tallarida RJ, Porreca F, Cowan A. Statistical analysis of drug-drug and site-site interactions with isobolograms. Life Sci 1989; 45: 947-61.

6 Tallarida RJ. Statistical analysis of drug combinations for synergism. Pain 1992; 49: 93-7.

7 Sato A, Schmidt RF. Somatosympathetic reflexes: afferent fibers, central pathways, discharge characteristics. Physiol Rev 1973; 53: 916-47.

8 Sato A, Sato $Y$, Schmidt RF. Somatosensory modulation of the cardiovascular system. In: Blaustein MP, Grunicke H, Pette D, Schultz G, Schweiger M (Eds.). Reviews of Physiology Biochemistry and Pharmacology 130, The Impact of Somatosensory Input on Autonomic Functions, 1st ed. Berlin, Springer, 1997: 115-66. 
9 Allen GV, Barbrick B, Esser MJ. Trigeminal-parabrachial connections: possible pathway for nociception-induced cardiovascular reflex responses. Brain Res 1996; 715: 125-35.

10 Allen GV, Pronych SP. Trigeminal autonomic pathways involved in nociception-induced reflex cardiovascular responses. Brain Res 1997; 754: 269-78.

11 Kitabata LM, McAllister RG, Taub A. Identification of central trigeminal nociceptors and the effects of nitrous oxide. Anesthesiology 1973; 38: 12-9.

12 Guo T-Z, Poree L, Golden W, Stein J, Fujinaga M, Maze $M$. Antinociceptive responses to nitrous oxide is mediated by supraspinal opiate and spinal $\alpha_{2}$ adrenergic receptors in the rat. Anesthesiology 1996; 85: 846-52.

13 Cahusac PMB, Morris R, Hill RG. A pharmacological study of the modulation of neuronal and behavioral nociceptive responses in the rat trigeminal region. Brain Res 1995; 700: 70-82.

14 Hara M, Kai Y, Ikemoto $\Upsilon$. Propofol activates GABA receptor-chloride ionophore complex in dissociated hippocampal pyramidal neurons of the rat. Anesthesiology 1993; 79: 781-8.

15 Almond JR, Westrum LE, Henry MA. Post-embedding immunogold labeling of gamma-aminobutyric acid in lamina II of the spinal trigeminal subnucleus pars caudalis: I. A qualitative study. Synapse 1996; 24: 39-47.

16 Wang C, Knowles MG, Chakrabarti MK, Whitwam JG. Clonidine has comparable effects on spontaneous sympathetic activity and afferent A- $\delta$ and C-fiber-mediated somatosympathetic reflexes in dogs. Anesthesiology 1994; 81: 710-7.

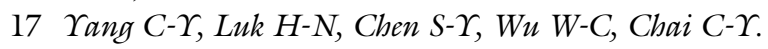
Propofol inhibits medullary pressor mechanisms in cats. Can J Anaesth 1997; 44: 775-81.

18 Fukunaga AF, Epstein RM. Sympathetic excitation during nitrous oxide - halothane anesthesia in the cat. Anesthesiology 1973; 39: 23-36.

19 Vinik HR, Bradley EL Jr, Kissin I. Isobolographic analysis of propofol-thiopental hypnotic interaction in surgical patients. Anesth Analg 1999; 88: 667-70.

20 Lennander $O ̈$, Henriksson B- $A$, Martner J, Biber B. Effects of fentanyl, nitrous oxide, or both, on baroreceptor reflex regulation in the cat. Br J Anaesth 1996; 77: 399-403.

21 Kazama T, Ikeda K, Morita K. The pharmacodynamic interaction between propofol and fentanyl with respect to the suppression of somatic or hemodynamic responses to skin incision, peritoneum incision, and abdominal wall retraction. Anesthesiology 1998; 89: 894-906. 